\title{
Pola Konsumsi Orang Dewasa Minangkabau dan Hubungannya Dengan Ukuran Lingkar Pinggang
}

\author{
Susmiatia \\ aProgram Studi Ilmu Keperawatan Fak.Kedokteran Universitas Andalas
}

\begin{abstract}
This study used Cross Sectional Study design comprising the population of adult's group age 30-60 years, live in Padang. 54 samples were taken by multi stage method from Bungus, Teluk Kabung, and Kecamatan Nanggalo. Data were taken by interview about dietary intake using Food Frequency Questionnaires (FFQ) and anthropometric measurement (body weight, height, and waist circumference). Then, data were analyzed with Spearman correlation analysis. This study revealed that respondents with waist circumference above average were 29 persons $(53,7 \%)$ and normal were 25 persons (46,7\%). Average energy, protein, fat, carbohydrate, and fiber was higher in the respondents with abnormal waist circumference that in those with normal. There was a significance difference between average consumption of energy, protein, fat, carbohydrate, and fiber between respondents with normal and abnormal waist circumference $(p<0.05)$. Using correlation analysis on consumption rates (energy, protein, fat, carbohydrate, and fiber) on waist circumference, it was found that all consumption rates were significantly correlated with waist circumference $(p<0.05)$. The strongest correlation was found with energy consumption with rho 0.719 .
\end{abstract}

Keywords: energy consumption rates, fat, protein, carbohydrate, fiber, waist circle

\begin{abstract}
Abstrak: Penelitian ini menggunakan desain Cross Sectional Study dengan populasi adalah masyarakat dewasa (30-60 tahun) yang bertempat tinggal di kota Padang, sedangkan sampel diambil secara multistage sampling yaitu Bungus Teluk kabung) dan kecamatan Nanggalo sebanyak 54 orang. Data dikumpulkan dengan melakukan interview intake makanan dengan menggunakan Food Freguency Questionaires (FFQ) dan pengukuran antropometri (Berat badan, tinggi badan dan lingkar pinggang). Selanjutnya data dianalisa dengan uji korelasi Spearman. Pada penelitian ini didapatkan responden yang mepunyai lingkar pinggang abnormal/diatas rata-rata 29 orang $(53,7 \%)$ dan lingkar pinggang normal sebanyak 25 orang $(46,7 \%)$. Rata-rata asupan energi, protein, lemak, karbohidrat, dan serat lebih tinggi pada responden dengan lingkar pinggang abnormal dibandingkan responden dengan lingkar pinggang normal . Terdapat perbedaan yang signifikan antara rata-rata tingkat konsumsi (energi, protein, lemak, karbohidrat dan serat) antara responden lingkar pinggang normal dan abnormal. $\mathrm{p}<0.05$. Dengan uji korelasi pada masing-masing tingkat konsumsi (energi, protein,lemak, karbohidrat dan serat ) terhadap lingkar pinggang didapatkan semua tingkat konsumsi mempunyai pengaruh yang signifikan dengan ukuran lingkar pingggang .p $<0,05$. Dan hubungan yang paling kuat dengan tingkat konsumsi energi dengan rho 0,719. Berdasarkan hasil penelitian dapat disimpulkan bahwa secara statistik didapatkan ada hubungan yang signifikan antara tingkat konsumsi energi,protein ,lemak, karbohidrat dan serat dengan ukuran lingkar pinggang. Dimana hubungannya positif artinya makin tinggi tingkat konsumsi makin tinggi ukuran lingkar pinggang.
\end{abstract}

Kata kunci: Tingkat konsumsi energi, lemak, protein, karbohidrat, serat, lingkar pinggang 
Nutrisi merupakan faktor penting terhadap perkembangan penyakit kardiovaskuler. Pola makan saat ini dengan berbagai pengaruh budaya, tekonologi, gaya hidup, sangat mempengaruhi kesehatan manusia secara umum di berbagai negara. Menurut statistik WHO, 70\% kematian dini disebabkan oleh penyakit diabetes, kanker, serangan jantung, dan stroke. Kematian dini tersebut, $50 \%$ diantaranya berhubungan dengan pola makan yang tidak baik atau kekurangan nutrisi. Diperkirakan bahwa 7 dari 10 cek kesehatan yang dilakukan seseorang ke dokter biasanya karena ada gangguan atau penyakit kronis, yang berhubungan dengan pola makan yang tidak baik.

Beberapa penelitian membuktikan bahwa penimbunan lemak dalam perut yang dikenal obesitas sentral lebih berkaitan dengan kejadian beberapa penyakit seperti diabetes melitus, dislipidemia, hipertensi, bahkan penyakit jantung koroner, dibandingkan obesitas berdasarkan Index Massa Tubuh (IMT). (Suastika, 2004).

Lingkar pinggang adalah ukuran antropometri yang dapat digunakan untuk menentukan obesitas sentral, dan kriteria untuk Asia Pasifik yaitu $\geq 90 \mathrm{~cm}$ untuk pria, dan $\geq 80 \mathrm{~cm}$ untuk wanita (WHO 2000). Lingkar pinggang berkorelasi kuat dengan obesitas sentral dan risiko penyakit kardiovaskular (Ford, 2002). Lingkar pinggang terbukti dapat mendeteksi obesitas sentral dan sindroma metabolik dengan ketepatan yang cukup tinggi dibandingkan indeks massa tubuh (IMT) dan lingkar panggul (Lean et al., 1995). Penumpukan lemak di seputar perut (obesitas sentral) menurut Profesor Anthony Barnett dari University of Birmingham dapat meningkatkan risiko penyakit diabetes dan penyakit jantung hingga 4 kali lipat.

Selama ini dokter sering melakukan pengecekan kolesterol, tekanan darah dan tingkat kegemukan / index massa tubuh (IMT) untuk mengukur risiko penyakit jantung, yang selama ini dikenal sebagai pembunuh nomor satu di AS dan juga negara-negara lain di dunia. Tetapi sangat jarang melakukan pemeriksaan lingkar pinggang yang dianggap sebagai prediktor kuat untuk terjadinya penyakit kardiovaskuler. Pola diet dapat digunakan untuk mengetahui hubungan diet dan penyakit. Beberapa faktor diet dapat berhubungan dengan kejadian penyakit kardiovaskuler. Sedikit penelitian yang telah dilakukan tentang hubungan pola konsumsi daengan lingkar pinggang (Millen BE ,2006)

\section{METODE}

Penelitian ini menggunakan desain Cross Sectional Study, dimana semua variabel diukur sekali dan dalam waktu yang bersamaan. Penelitian dilakukan di kota Padang Sumatera Barat mulai AprilNovember 2009.

Populasi adalah masyarakat dewasa ( 30-60 tahun) yang bertempat tinggal di kota Padang, sedangkan sampel diambil secara multistage sampling yaitu daerah pantai (Kecamatan Bungus Teluk kabung ) dan daerah daratan ( kecamatan Nanggalo). Sampel sebanyak 54 orang

\section{Cara Kerja}

Data dikumpulkan oleh sebuah team survey, yang terdiri dari :

- Supervisor : Peneliti

- Mahasiswa senior akademi Gizi : untuk melakukan interview intake makanan dilapangan dan pengukuran antropometri ( Berat badan, tinggi badan dan lingkar pinggang)

Sebelum dilakukan pengumpulan data dilapangan, dilakukan pelatihan/training terhadap team survey meliputi pengenalan bentuk format dan cara pengisian kuesioner.

1. Pengukuran lingkar pinggang dilakukan dengan pita centimeter cara direkomendasikan oleh WHO tahun 1995, yaitu : 
- Penderita berdiri dengan jarak antar kaki $25-30 \mathrm{~cm}$.

- Pengukuran dilakukan melalui titik pertengahan antara tepi inferior dari costa terbawah dengan crista iliaca.

- Lingkaran harus dipastikan sesuai dengan bidang horizontal, dengan pemeriksa duduk di samping penderita untuk memudahkan menempatkan lingkaran dalam bidang horizontal.

- Pita dililitkan setepat mungkin tetapi tidak boleh sampai menekan jaringan lunak.

2. Untuk mendapatkan informasi tentang tingkat konsumsi zat gizi seperti energi, lemak, karbohidrat protein dan serat diperoleh melalui wawancara terstruktur yang dipandu dengan menggunakan Food Freguency Questionaires (FFQ) . Hal yang ditanyakan dalam FFQ ini adalah frekuensi makan (dalam hari, minggu, bulan tahun) dan porsi makan (gram) untuk jenis makanan sumber karbohidrat, protein (hewani, nabati), sayuran, buah-buahan dan berbagai jenis jajanan.

Hasil yang didapat dianahsa statistik dengan menggunakan program SPSS 17.0. yaitu korelasi antara asupan energi, karbohidrat, serat, dan lemak dengan lingkar pinggang. Selanjutnya dilakukan analisis regresi linier sederhana untuk mengetahui bentuk hubungan antara variabel bebas asupan energi, karbohidrat, serat, dan lemak dengan variabel terikat lingkar pinggang.

\section{HASIL DAN PEMBAHASAN}

Kota Padang adalah ibukota Propinsi Sumatera Barat dengan luas $694,96 \mathrm{~km}^{2}$ memiliki penduduk sebanyak 784.740 jiwa dan kepadatan penduduk sekitar 1.129 jiwa/ $\mathrm{km}^{2}$. Kota Padang terdiri dari 11 kecamatan dan 104 kelurahan

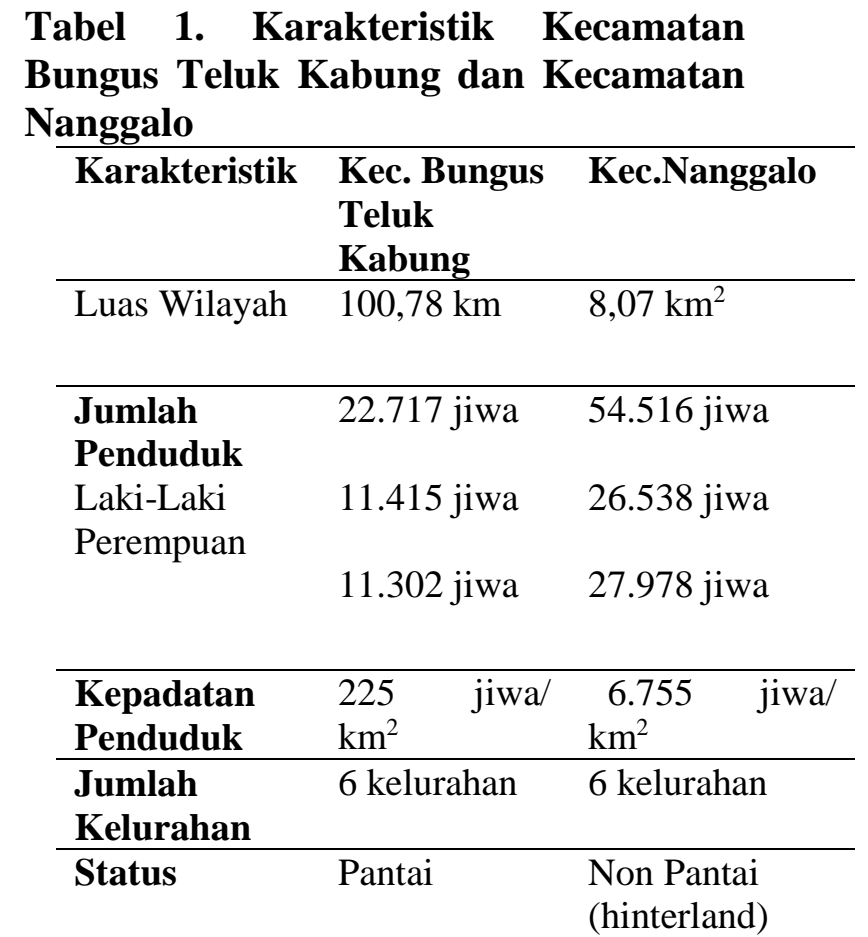

Sumber :

1. Padang Dalam Angka tahun 2004, BPS Propinsi Sumatera Barat

2. Kantor Kecamatan Bungus Teluk Kabung dan Kantor Kecamatan Nanggalo

Responden pada penelitian ini yaitu laki-laki 13 orang $(24,1 \%)$, dan perempuan dengan 41 orang $(75,90 \%)$. Status perkawinan responden yaitu sebanyak 83,3 \% status kawin. Untuk tingkat pendidikan responden, terbanyak $29,6 \%$ berpendidikan SMA. Hampir sebagian besar pekerjaan responden adalah bekerja $61,1 \%$. Sedangkan responden yang mepunyai lingkar pinggang abnormal/diatas rata-rata 29 orang $(53,7$ $\%)$.

Tabel 2 : Karakteristik responden

\begin{tabular}{lcc}
\hline Variabel & Jumlah & \% \\
\hline Jeniskelamin (n =54) & & \\
Laki-laki & 13 & 24,1 \\
Perempuan & 41 & 75,9 \\
Status pekerjaan & & \\
Bekerja & 33 & 61,1 \\
Tidak bekerja & 21 & 38,9 \\
Tingkat Pendidikan & & \\
(n=54) & & \\
Tidak sekolah & 15 & 27,8 \\
Tamat SD/MI & 7 & 13,0 \\
Tamat SLTP/Sederajat & 11 & 20,4 \\
\hline
\end{tabular}


Tamat SLTA/Sederajat

Tamat Akademi/PT

Status Perkawinan

$(\mathbf{n}=\mathbf{5 4})$

Belum Kawin

Kawin

Janda/Duda

Lingkar pinggang

$(\mathbf{n}=54)$

Abnormal

Normal

$\begin{array}{cl}16 & 29,6 \\ 5 & 9,3\end{array}$

$1 \quad 1,9$

$45 \quad 83,3$

$8 \quad 14,8$

$29 \quad 53,7$

$25 \quad 46,3$

Karakteristik

responden berdasarkan jenis kelamin, status pekerjaan, aktivitas fisik, didapatkan tidak ada hubungan yang bermakna dengan lingkar pinggang.

Sedangkan status gizi (obesitas dan non obesitas) terdapat hubungan yang bermakna dengan lingkar pinggang $\mathrm{p}<$ 0.05. Lingkar pinggang abnormal banyak terdapat pada responden obesitas dibandingkan non obesitas.

\section{Gambaran Lingkar pinggang} responden menurut jenis kelamin, demografi, status gizi dan gaya hidup

Tabel 3. Distribusi Lingkar pinggang responden menurut jenis kelamin, demografi, status gizi, gaya hidup

\begin{tabular}{|c|c|c|c|c|}
\hline & \multicolumn{2}{|c|}{ Lingkar Pinggang } & \multirow[t]{2}{*}{ total } & \multirow[b]{2}{*}{$\mathbf{p}$} \\
\hline & Normal & Abnormal & & \\
\hline $\begin{array}{l}\text { Jenis kelamin } \\
\text { Laki-laki } \\
\text { Perempuan }\end{array}$ & $\begin{array}{c}8(61,5 \%) \\
17(41,5 \%)\end{array}$ & $\begin{array}{c}5(38,5 \%) \\
24(58,5 \%)\end{array}$ & $\begin{array}{c}13(100 \%) \\
41100 \%)\end{array}$ & 0,21 \\
\hline $\begin{array}{l}\text { Status pekerjaan } \\
\text { Bekerja } \\
\text { Tidak bekerja }\end{array}$ & $\begin{array}{c}17(51,5 \%) \\
8(38,1 \%)\end{array}$ & $\begin{array}{l}16(48,5 \%) \\
13(61,9 \%)\end{array}$ & $\begin{array}{l}33(100 \%) \\
21(100 \%)\end{array}$ & 0.49 \\
\hline $\begin{array}{l}\text { Status Gizi } \\
\text { Obes } \\
\text { Non-Obes }\end{array}$ & $\begin{array}{c}1(3,8 \%) \\
24(85,7 \%)\end{array}$ & $\begin{array}{c}25(96,2 \%) \\
4(14,3 \%)\end{array}$ & $\begin{array}{l}26(100 \%) \\
28(100 \%)\end{array}$ & $\mathbf{0 . 0 0}$ \\
\hline $\begin{array}{l}\text { Aktifitas Fisik } \\
\text { Aktif } \\
\text { Kurang Aktif }\end{array}$ & $\begin{array}{l}11(40,7 \%) \\
14(51,9 \%)\end{array}$ & $\begin{array}{l}16(59,3 \%) \\
13(48,1 \%)\end{array}$ & $\begin{array}{l}27(100 \%) \\
27(100 \%)\end{array}$ & 0.41 \\
\hline
\end{tabular}

4.Gambaran Rata-rata umur, lingkar pinggang dan BMI

Tabel 4. Rerata umur, lingkar pinggang dan BMI responden

\begin{tabular}{|c|c|c|}
\hline & Mean \pm SD & Min-Max \\
\hline \multirow{2}{*}{$\begin{array}{c}\text { Umur } \\
\text { Lingkar pinggang } \\
\text { Body Masa Index }\end{array}$} & $47,48 \pm 9,35$ & $31-66$ \\
\cline { 2 - 3 }$($ BMI) $(\mathbf{c m} / \mathbf{m} 2)$ & $88,68 \pm 15,59$ & $58,00-124,10$ \\
\cline { 2 - 3 } & $24,22 \pm 5,51$ & $14,54-35.55$ \\
\hline
\end{tabular}

Rata-rata lingkar pinggang responden $88,68 \mathrm{~cm} \pm 15,59 \mathrm{SD}$ dengan lingkar pingggang minimum $58 \mathrm{~cm}$ dan maksimum $124 \mathrm{~cm}$. Rata - rata Body

Hasil analisis terhadap tingkat konsumsi energi rata-rata 1609,26 kkal \pm 436,26 , rata-rata protein $44,96 \mathrm{gr} \pm 14,87$,
Massa Indeks 24,22 $\pm 5,51$ SD dan minimum 14,54 dan maksimum 35,55.

sedangkan lemak 42,22 gr $\pm 16,75$, karbohidrat rata-rata 260,68 gr $\pm 70,80$, dan rata-rata serat yaitu $10.01 \pm 3.89$. 
Untuk lebih jelas dapat dilihat pada tabel berikut ini:

Tabel 5 : Rerata sebaran subjek berdasarkan tingkat konsumsi

\begin{tabular}{|l|c|c|}
\hline & Mean \pm SD & Min-Max \\
\hline Energi & & $937,30-2724,00$ \\
\hline $\begin{array}{l}\text { Protein } \\
\text { Lemak }\end{array}$ & $1609,26 \pm 436,26$ & $20,00-93,80$ \\
\cline { 2 - 3 } Karbohidrat & $44,96 \pm 14,87$ & $17,10-9109,50$ \\
\cline { 2 - 3 } Serat & $42,22 \pm 16,75$ & $156,30-410,50$ \\
\cline { 2 - 3 } & $260,68 \pm 70,80$ & $4,20-22,30$ \\
\hline
\end{tabular}

Tabel 6 : Rerata Tingkat Konsumsi menurut Lingkar Pinggang

\begin{tabular}{|l|c|c|c|}
\hline \multirow{2}{*}{$\begin{array}{l}\text { Tingkat konsumsi } \\
\text { Energi }\end{array}$} & Normal & p & \\
\hline Protein & $1366.47 \pm 310.11$ & $1818.56 \pm 423.58$ & $\mathbf{0 , 0 0 0}$ \\
\hline Lemak & $37.85 \pm 9.04$ & $51.09 \pm 310.11$ & $\mathbf{0 , 0 0 0}$ \\
\hline Karbohidrat & $33.89 \pm 9.86$ & $49.40 \pm 18.22$ & $\mathbf{0 , 0 0 0}$ \\
\hline Serat & $225.44 \pm 59.61$ & $291.06 \pm 66.17$ & $\mathbf{0 , 0 0 0}$ \\
\hline
\end{tabular}

Rerata asupan energi, protein, lemak, karbohidrat, dan serat lebih tinggi pada responden dengan lingkar pinggang abnormal dibandingkan responden dengan lingkar pinggang normal. Terdapat perbedaan yang signifikan antara rata-rata tingkat konsumsi (energi, protein, lemak, karbohidrat dan serat) antara responden lingkar pinggang normal dan abnormal. $\mathrm{p}$ $<0.05$.

Tabel 7. : Korelasi Tingkat konsumsi energi, Protein, Lemak, karbohidrat dan Serat dengan Lingkar pinggang

\begin{tabular}{|l|l|l|r|r|r|r|r|}
\hline & & Energi & Protein & Lemak & \multicolumn{1}{c|}{ Karbohidrat } & SERAT \\
\hline $\begin{array}{l}\text { Spearman's } \\
\text { rho }\end{array}$ & Ip & $\begin{array}{l}\text { Correlation } \\
\text { Coefficient }\end{array}$ & $.719^{* *}$ & $.634^{* *}$ & $.500^{* *}$ & $.652^{* *}$ & $.489^{* * *}$ \\
\cline { 2 - 7 } & & .000 & .000 & .000 & .000 & .000 \\
\cline { 2 - 7 } (2-tailed) & $\mathbf{N}$ & 54 & 54 & 54 & 54 & 54 \\
\hline
\end{tabular}

Dengan uji korelasi pada masingmasing tingkat konsumsi (energi, protein,lemak, karbohidrat dan serat ) terhadap lingkar pinggang didapatkan semua tingkat konsumsi mempunyai pengaruh yang signifikan dengan ukuran lingkar pingggang $. p<0,05$. Dan hubungan yang paling kuat dengan tingkat konsumsi energi dengan rho 0,719.

Penelitian ini pada dasarnya untuk melihat hubungan antara pola konsumsi energi, protein, lemak, karbohidrat dan serat dengan ukuran lingkar pinggang.
Komponen yang diukur adalah jumlah asupan responden dan berapa ukuran lingkar pinggangnya. Pada penelitian ini didapatkan responden yang mepunyai lingkar pinggang abnormal/diatas rata-rata lebih banyak yaitu 29 orang $(53,7 \%)$ dan lingkar pinggang normal sebanyak 25 orang $(46,7 \%)$. Tingginya persentase responden dengan lingkar pinggang abnormal disebabkan sebagian besar responden sudah diatas 40 tahun.

Dimana perempuan lebih banyak ukuran lingkar pinggang abnormal dibandingkan 
laki-laki $(58,5 \%)$. Responden yang tidak ekerja lebih banyak ukuran lingkarpinggang abnormal (61,9\%).tetapi secara statistik tidak ada perbedaan yang signifikan $\mathrm{p}>0,05$. Sedangkan responden yang obese hampir seluruhnya mempunyai lingkar pinggang yang abnormal $(96,2 \%)$, dan ada perbedaan yang signifikan antara lingkar pinggang obesitas dan non obesitas $\mathrm{p}<0,05$

Secara garis besar, terdapat perbedaan rata-rata tingkat konsumsi energi, protein, lemak, karbohidrat dan serat dengan ukuran lingkar pinggang . Rata-rata asupan energi, protein, lemak, karbohidrat, dan serat lebih tinggi pada responden dengan lingkar pinggang abnormal dibandingkan responden dengan lingkar pinggang normal.

Berdasarkan analisis korelasi dengan uji Spearman pada masing-masing tingkat konsumsi (energi, protein,lemak, karbohidrat dan serat ) terhadap lingkar pinggang didapatkan semua tingkat konsumsi mempunyai hubungan yang signifikan dengan ukuran lingkar pingggang $\cdot \mathrm{p}<0,05$. Dan hubungan yang paling kuat dengan tingkat konsumsi energi dengan rho 0,719 .

Penelitian ini sejalan dengan penelitianyang dilakukan Freiberg MS,2004; Rikard A ,2007; Azadbakht L,2007. Penelitian cross sectional mendapatkan intake rendah/sedang karbohidarat, tinggi serat, buah dan sayuran ( tinggi vitamin $\mathrm{C}$ dan carotene) dan sedikit konsumsi alcohol dapat menurunkan resiko sindroma metabolik . Sedangkan konsumsi tinggi lemak dapat meningkatkan resiko sindroma metabolik. (Anderson AS, 2000;Schulze MB, 2004; Hu G,2006; Pamela L,2008). Lingkar pinggang merupakan salah satu komponen sindroma metabolik.

Asupan makanan berlebihan dan/atau penurunan pengeluaran energi menimbulkan keseimbangan energi positif. Keseimbangan energi positif yang terjadi dari asupan makanan berlebihan terutama berasal dari kelebihan asupan energi dan sumber karbohidrat, sehingga terjadi akumulasi lemak berlebihan di jaringan adiposa abdominal yang akhirnya akan menambah ukuran lingkar pinggang (obesitas sentral).

Pada obesitas terjadi peningkatan asam lemak bebas dan peningkatan distribusi asam lemak di hati. Hal tersebut meningkatkan proses glukoneogenesis, menghambat ambilan serta penggunaan glukosa di otot. Akumulasi trigliserida di hati dan di otot akan mengakibatkan resistensi insulin. Selain itu jaringan lemak ternyata menghasilkan beberapa sitokin dan hormon yang menghambat kerja insulin. Hormon insulin merupakan regulator penting pada metabolisme karbohidrat, lipid dan protein, maka setiap gangguan aksi insulin akan menimbulkan konsekuensi metabolik yang tampak pada sindroma metabolik. Obesitas merupakan suatu kondisi proinflamasi yang menimbulkan resistensi insulin. Kondisi ini dapat memicu terjadinya dislipidemia, intoleran terhadap glukosa dan peningkatan tekanan darah.

\section{KESIMPULAN DAN SARAN}

1. Pada penelitian ini didapatkan ukuran lingkar pinggang rata-rata $88,68 \mathrm{~cm} \pm$ 15,59 SD. Dan responden yang mepunyai lingkar pinggang abnormal/diatas rata-rata lebih banyak yaitu 29 orang $(53,7 \%)$ dan lingkar pinggang normal sebanyak 25 orang $(46,7 \%)$.

2. Rata-rata tingkat konsumsi energi, protein, lemak, karbohidrat, dan serat lebih tinggi pada responden dengan lingkar pinggang abnormal dibandingkan responden dengan lingkar pinggang normal. $\mathrm{P}<0,05$

3. Tingkat konsumsi energi, protein, lemak, karbohidrat, dan serat mempunyai hubungan yang signifikan dengan ukuran lingkar pingggang .p < 0,05 . 
SARAN

1. Untuk menjadikan lingkar pinggang sebagai prediktor terhadap timbulnya penyakit deggeneratif dan kontrol asupan energi, karbohidrat,protein, lemak dan serat

2. Melakukan penelitian lebih lanjut yang melibatkan faktor aktifitas fisik

\section{DAFTAR PUSTAKA}

Adriansjah H, Adam JMF. Sanusi H. Sambo AP. 2003. Waist circumference as a screening approach of metabolik syndrome in men. The $12^{\text {th }}$ Congress of the ASEAN Federation of Endocrine Societies, Singapore.

Lipoeto, N.I., Agus, Z., Masrul, M., et al. 2001. Contemporary Minangkabau Food Culture in West Sumatra, Indonesia. Asia Pasific J Clin Nutr. 10(1) : 10-16.

Millen BE, Pencina MJ, Kimokoti RW, Zhu L, Meigs JB, Ordovas JM, andAgostino RBD. 2006. Nutritional risk and the metabolik syndrome in women: opportunities for preventive intervention from the Framingham Nutrition Study1Am J Clin Nutr ;84:434-41

Pamela L. Lutsey, Lyn M. Steffen, Stevens J, 2008. Dietary Intake and the Development of the Metabolik SyndromeCirculation.;117:754-761.)

Soegono, S. Desember. 2005. Perjalanan obesitas menuju Diabetes dan penyakit kardiovaskular. Edisi khusus

Sonnenberg L, Pencina M, Kimokoti R, et al. 2005. Dietary patterns and the metabolik syndrome in obese and non-obese Framingham women. Obes Res;13:153-62.

Suastika K. 2004. Metabolik Syndrome Rural Population of Bali. International Journal of Obesity and Related Metabolik Disorders. 28:S55
Van Gaal LF, Mertens IL \& De Block CE. 2006. Mechanisms linking obesity with cardiovascular disease. Nature 444, 875-880 (14 December)

World Health Organization, 1999. Obesity: Preventing and managing the global epidemic. Report of a WHO Consultation. World Health Organization, Geneva (Tech Rep Ser 894) 